\title{
PIECES Framework and Importance Performance Analysis Method to Evaluate the Implementation of Information Systems
}

\author{
Ahmad Fatoni $^{1 *}$, Kusworo Adi ${ }^{2}$, Aris Puji Widodo ${ }^{3}$ \\ ${ }^{1}$ Master of Information System, Post Graduated School, Diponegoro University, Semarang, Indonesia \\ ${ }^{2}$ Department of Physics, Faculty of Science and Mathematics, Diponegoro University, Semarang, Indonesia \\ ${ }^{3}$ Department of Informatics, Faculty of Science and Mathematics, Diponegoro University, Semarang, \\ Indonesia
}

\begin{abstract}
Work plan and budget are solutions in gathering budget planning data and uniforming budgeting. the purpose of the work plan and budget is to assist all work units in preparing and managing the budget plan without mixing it with other units. The importance of performances analysis method and PIECES framework were chosen in this study because both of method were able to classify the insitution problems, opportunities and information system goals. PIECES Framework as a questionnaire criteria to responding the users and the Importance Performance Analysis method as a result of questionnaire data from 88 respondents in the form of Quadrants. The aim of the research to evaluate information systems is a user satisfaction and importance of information systems. The calculation results with IPA method shows that the user's satisfaction averages and the importance of information system quality is $93.71 \%$. However, there are a few deficiencies that need to be improved in the development of information systems, work plans and annual budgets such as system quality, accurate informations, estimated cost of building the system, security systems efficiency and service improvement for users.
\end{abstract}

Keywords. PIECES Framework; Importance Performance Analysis; Information System; User Satisfaction.

\section{Introduction}

Budget is a form of statement regarding the estimated performance to be achieved over a certain period of time expressed in financial measures, while budgeting is the purpose of preparing a process or method for preparing a budget [1]. Work plan and budget are solutions in gathering budget planning data and uniforming budgeting. the purpose of the work plan and budget is to assist all work units in preparing and managing the budget plan without mixing it with other units. is needed to provide direction and guidance for the work unit actors

* Corresponding author: ahmadfatoni2104@gmail.com 
in the direction of change or better goals (improvement, development) with little risk and to reduce future uncertainty. Work plan and budget are a form of unity from the details of the measured work plan containing the budget allocation that has been set by the work unit, work agenda / targets / strategies and program of activities to be implemented. Work plans and budgets that focus on current (short-term) operations and especially those related to the goal of achieving efficiency.

Annual work plan and budget or RKAT system are prepared by Diponegoro University to collect planning and budgeting data that will be carried out by Undip in one year. Thus, the management of work plans in Undip can be planned and realized properly with transparent and accountable mechanisms. Diponegoro University RKAT Information System is an application to enter performance targets based on performance indicators and activities. This system helps all work units in setting performance targets to be achieved online. Each unit can fill Sub-activities together with filling the budget through the annual work plan and budget or RKAT without mixing with other units. In addition, the RKAT is also used to revise the budget from the government that has been determined by the Budget Unit Per Work Unit (SAPSK) or Budget Implementation Entry List (DIPA). The budget revision mechanism refers to the Minister of Finance Regulation Number 206/PMK.02/2018 concerning Amendments to the Minister of Finance Regulation Number 10/PMK.02/2017 and Diponegoro University Rector Regulation number 25 of 2018.

To find out if the RKAT system is running as expected, it needs an evaluation process on the performance of the information system. Evaluation is a form of activity instrument that has been planned to assess a problem that occurred and the results can be compared as a benchmark to obtain conclusions and find solutions to solve problems that will arise. While the evaluation of information systems can be done in different ways and at different levels, depending on the purpose of the evaluation. The purpose of this information system evaluation is to assess the technical capability, operational implementation, and system utilization [2].

The PIECES Framework and Importance Performance Analysis (IPA) methods are selected in this study as they can translate the opinions of users in the form of questionnaire statements. While the IPA method is used to manage the results of the questionnaire, so that it can produce four quadrants of IPA to know which aspects should be done repair and which should be improved from the RKAT information system.

PIECES Framework method is a framework containing the categories of classification and problem-solving problems. The classification is divided into six categories according to the sequence, namely Performance, Information and Data, Economics, Control and Security, Efficiency, and Service. In addition, PIECES has three impetus namely Problem, Opportunity, and Directive [3]. In addition the PIECES Framework method also as a framework used to classify a problem, opportunities, and directives contained in the scope definition of analysis and system design. With this skeleton, it can be generated new things that can be considered in developing the system [4].

Importance Performance Analysis method is applied to measure the level of customer satisfaction and management strategy. The techniques of this method can help to measure the satisfaction of system services and diagnose the shortcomings of the system, as well as to establish priorities in the development of information systems of program plans and subsequent annual activities. Previous research on the implementation of the Importance Performance Analysis method, among others, to understand the level of importance and satisfaction level of the visitors of the zoo [5], help nurses in evaluating the satisfaction service of information systems in hospitals [6] and assess the perception of customers in the use of smartphone applications to 20 hotel network applications [7].

The IPA method can also be implemented with the methods of SWOT analysis (Strengths Weaknesses Opportunities and Threats) in formulating the strategic planning of the 
Organization so that it becomes more efficient. The SWOT factors that must be maintained or upgraded can clearly be identified as the point of view of the customer [8].

\section{LITERATUR REVIEW}

\subsection{Information System}

Information systems are a combination of brainware, hardware, software, communication networks, data sources, rules, and procedures for storing, displaying, changing, and deleting information within an organization [9]. While the information system are also interconnected components and work together to collect, process, store and distribute information to support decision making, coordination, control, analysis and visualization in an organization [10].

\subsection{PIECES Framework}

The PIECES framework method is a framework used to classify a problem, opportunities, and directives contained in the scope definition of analysis and system design, so that it can be generated new things that can be considered in developing the system [11]. In PIECES there are six variables used to analyze the information system, namely:

1) Performance : To know the performance of a system, whether it is running properly or not, this is measured based on the speed, accuracy, and number of findings of the data generated.

2) Information and Data : To know how much and how clear the information will be generated for a single search.

3) Economics : To know the effectiveness of the implementation of the system seen in terms of financial and cost incurred.

4) Control and Security : To determine the extent to which supervision and control is performed in order for the system to run properly.

5) Efficiency : To know the efficiency of the system.

6) Service : To know how the service is done and to know the related problems about the service.

\subsection{Importance Performance Analysis}

Metode Importance Performance Analysis (IPA) ditemukan oleh Martilla dan James pada tahun 1977 sebagai analisis tingkat kepuasan pelanggan terhadap produk atau layanan organisasi. Metode IPA juga digunakan untuk mengukur tingkat kepuasan dan kepentingan pengguna berdasarkan atribut layanan jasa dan produk [12]. Penerapan metode IPA sebagai analisa untuk mengukur tingkat kepuasan pelayanan jasa yang menggambarkan bentuk kuadran-kuadran pada peta importance performance matrix [13].

The Importance Performance Analysis (IPA) technique combines the measurement of factors of importance (expectations) and performance levels (perception) into a twodimensional graphical form that makes it easy to explain data and get practical suggestions [14]. This Plot groups the attributes into four quadrants to set the allocation of limited resources, as shown in Figure 1. 


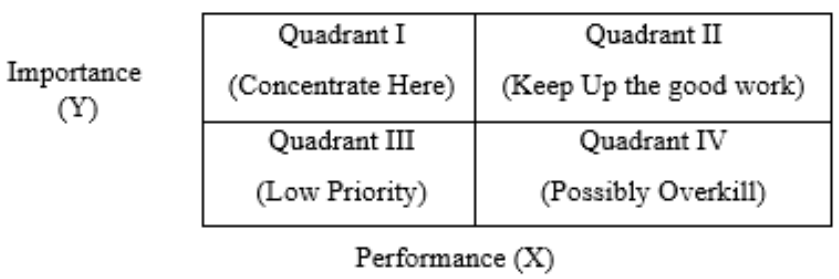

Fig. 1. Distribution quadrant IPA

a. Quadrant I, the factors found in this quadrant have a high level of importance but not in accordance with the performance of the user so as to allocate resources to improve performance as expected.

b. Quadrant II, the factors found in this quadrant have a high level of importance accompanied by a high level of performance and in accordance with the expectations of the user so that the achievement should be maintained.

c. Quadrant III, the factor found in this quadrant has a low level of importance accompanied by a level of performance not too prioritized with relatively low expectations, thus providing too little benefit to the user's perceived.

d. Quadrant IV, the factor contained in this quadrant has a low level of importance accompanied by an excessively high degree of performance, so that the university must allocate this quadrant resource to other quadrants requiring improved performance.

\section{Research Method}

\subsection{Type of Research}

This type of research conducted by researchers is a quantitative descriptive that aims to describe, describe the sharing of conditions and situations from various assumptions in the community which is used as an object of research, in this study the object is the Information Systems User [15].

\subsection{Research Instruments}

The research instrument used was a questionnaire as an instrument to obtain information about the level of satisfaction and importance of the information system to users. This questionnaire was made based on 6 variables from PIECES Framework. The object of this research is an information system of annualy work plan and budget at Diponegoro University and the source of primary data or samples is 88 users who have used the system.

\subsection{Data collection}

Data collection was carried out using survey techniques based on the PIECES framework, namely by distributing online questionnaire statements to users of the Diponegoro university's annual program planning and activity program. The Questionnaire is created using the PIECES Framework variable shown in table 1 and 2. 
Table 1. Domain PIECES Framework

\begin{tabular}{clcc}
\hline No & \multicolumn{1}{c}{ Variable } & Code & Number of statements \\
\hline 1 & Performance & K1 & 5 \\
2 & Information and Data & K2 & 8 \\
3 & Economy & K3 & 2 \\
4 & Control and Security & K4 & 3 \\
5 & Efficiency & K5 & 2 \\
6 & Service & K6 & 4 \\
\hline
\end{tabular}

Table 2. PIECES Framework Statement List

\begin{tabular}{lr}
\hline No & Variable \\
\hline 1 & Performance
\end{tabular}

2 Information and Data

\section{Economy}

4 Control and Security
Statement accessible by user.

Information Systems annual program plans and activities can operate a number of orders in a relatively short time, without experiencing obstacles.

Information System annual program plans and activities always run stable.

The amount of data that can be processed by Information System annual program plans and activities in time units is in accordance with what is expected.

The Total amount of time required to perform data processing to generate information is done quickly.

Data stored by RKAT information system has been stored according to which is inserted into the system.

RKAT Information System was not able to store data that was not to supposed.

Data that contains errors or incorrect data may be stored by the RKAT information system.

The information generated by the RKAT information system is as required.

Information generated by the RKAT information system just in time.

The information Format generated by RKAT information system is useful and can be used by users of such systems.

Information presented information systems RKAT is easy to learn and understand.

Information generated by the RKAT information System are reliable or trustworthy.

The costs incurred by Diponegoro University became lighter with the information system of RKAT compared to using conventional means.

There are significant changes in terms of development and growth in the presence of information system RKAT.

The form of security contained in the RKAT information system is already able to maintain data or information from various forms of cheating or crime. 


\begin{tabular}{|c|c|c|}
\hline No & Variable & Statement \\
\hline \multirow{4}{*}{5} & \multirow{4}{*}{ Efficiency } & $\begin{array}{l}\text { Management in authorizing and determining access control } \\
\text { to the use and operation of the system is obvious. }\end{array}$ \\
\hline & & There is centralized control over data usage. \\
\hline & & $\begin{array}{l}\text { The system used now further lightens students both in terms } \\
\text { of cost and time. }\end{array}$ \\
\hline & & $\begin{array}{l}\text { The use of information systems RKAT is very instrumental } \\
\text { in the program plan and annual university activities. }\end{array}$ \\
\hline \multirow[t]{4}{*}{6} & \multirow[t]{4}{*}{ Service } & $\begin{array}{l}\text { The party that handles the system provides assistance to } \\
\text { users in the use of information systems RKAT. }\end{array}$ \\
\hline & & $\begin{array}{l}\text { The RKAT information system is easy to use, learn and } \\
\text { understand. }\end{array}$ \\
\hline & & $\begin{array}{l}\text { The RKAT information system is coordinated and } \\
\text { integrates with other systems. }\end{array}$ \\
\hline & & $\begin{array}{l}\text { The RKAT information System can provide your } \\
\text { satisfaction as a user in need of information. }\end{array}$ \\
\hline
\end{tabular}

\subsection{Importance Performance Analysis Method}

The process of data analysis using the Importance Performance Analysis (IPA) method is obtained from the questionnaire using the Likert scale [18], which aims to measure the level of satisfaction and interest of the respondents based on the approval of a series of statements given.

Table 3. Likert Scale of Satisfaction

\begin{tabular}{lc}
\hline \multicolumn{1}{c}{ Answer Options } & Score \\
\hline Very Satisfied & 5 \\
Satisfied & 4 \\
Quite Satisfied & 3 \\
Unsatisfied & 2 \\
Very Dissatisfied & 1 \\
\hline
\end{tabular}

Table 4. Likert Scale of Interest

\begin{tabular}{lc}
\hline \multicolumn{1}{c}{ Answer Options } & Score \\
\hline Very Important & 5 \\
Important & 4 \\
Hesitant & 3 \\
Not Important & 2 \\
Not very Important & 1 \\
\hline
\end{tabular}

Then determine the average use of the satisfaction level by using the following equation of the formula.

$$
R K=\frac{J S K}{J K}
$$

Where $R K=$ average satisfaction or importance, $J S K=$ Amount of questionnaire scores, $J K=$ Amount of questionnaires [19]. 
The Importance Performance Analysis calculation is done in three steps.

Step I : Calculates the level of conformity to determine the magnitude of the user's satisfaction level to the existing service, using the following formula.

$$
T_{k}=\frac{X}{Y} * 100 \%
$$

with $T_{k}$ states the level of conformance from users, $X$ declares the value of the average performance assessment, and $Y$ declares the value of the average user expectation rating.

Step II : Determining the position map of the points of interest and performance, creating a chart that is delimited with two intersecting lines perpendicular, thus forming the four intersecting quadrants at the following points.

$$
\begin{aligned}
& \bar{X}=\frac{\sum X i}{n} \\
& \bar{Y}=\frac{\sum Y i}{n}
\end{aligned}
$$

where $\bar{X}$ states the average value of expectations or interests, $\bar{Y}$ states the average score of perception or performance, and $n$ state amount of respondents [20].

Table 5. Average Satisfaction and Interest

\begin{tabular}{cll}
\hline Value Range & Satisfaction Predicate & Predicate Interests \\
\hline $1,00-1,79$ & Very Dissatisfied & Not Very Important \\
$1,80-2,59$ & Unsatisfied & Not important \\
$2,60-3,39$ & Quite Satisfied & Pretty Important \\
$3,40-4,79$ & Satisfied & Important \\
$4,80-5,00$ & Very Satisfied & Very Important \\
\hline
\end{tabular}

Step III : Analyzing all variables that have an influence on the quality of the service by creating graphs of the four quadrants.

\section{Result and Discussion}

The results and discussion of the research that has been carried out are based on the research methodology.

\subsection{Research Instruments}

The Research Instrument uses a list of questions that can be seen in table 5 .

\subsection{Data Analysis and Calculation Results}

Based on the data analysis and calculation results of the average number of satisfaction and importance using the PIECES framework above that has been collected from 88 respondents obtained data as shown in table 6 and table 7 . 
Table 6. Tabulate the questionnaire level of user satisfaction

\begin{tabular}{lcc}
\hline \multicolumn{1}{c}{ Variable } & Average & Predicate \\
\hline Performance & 3,99 & Satisfied \\
Information and Data & 3,99 & Satisfied \\
Economics & 3,82 & Satisfied \\
Control and Security & 3,91 & Satisfied \\
Efficiency & 4,14 & Satisfied \\
Service & 3,96 & Satisfied \\
\hline
\end{tabular}

Table 7. Tabulate the questionnaire level of user interest

\begin{tabular}{lcl}
\hline \multicolumn{1}{c}{ Variable } & Average & Predicate \\
\hline Performance & 4,30 & Important \\
Information and Data & 4,22 & Important \\
Economics & 3,99 & Important \\
Control and Security & 4,35 & Important \\
Efficiency & 4,27 & Important \\
Service & 4,30 & Important \\
\hline
\end{tabular}

From this data, an analysis process using the IPA method is then carried out, in order to obtain the results as shown in the fig. 2 .

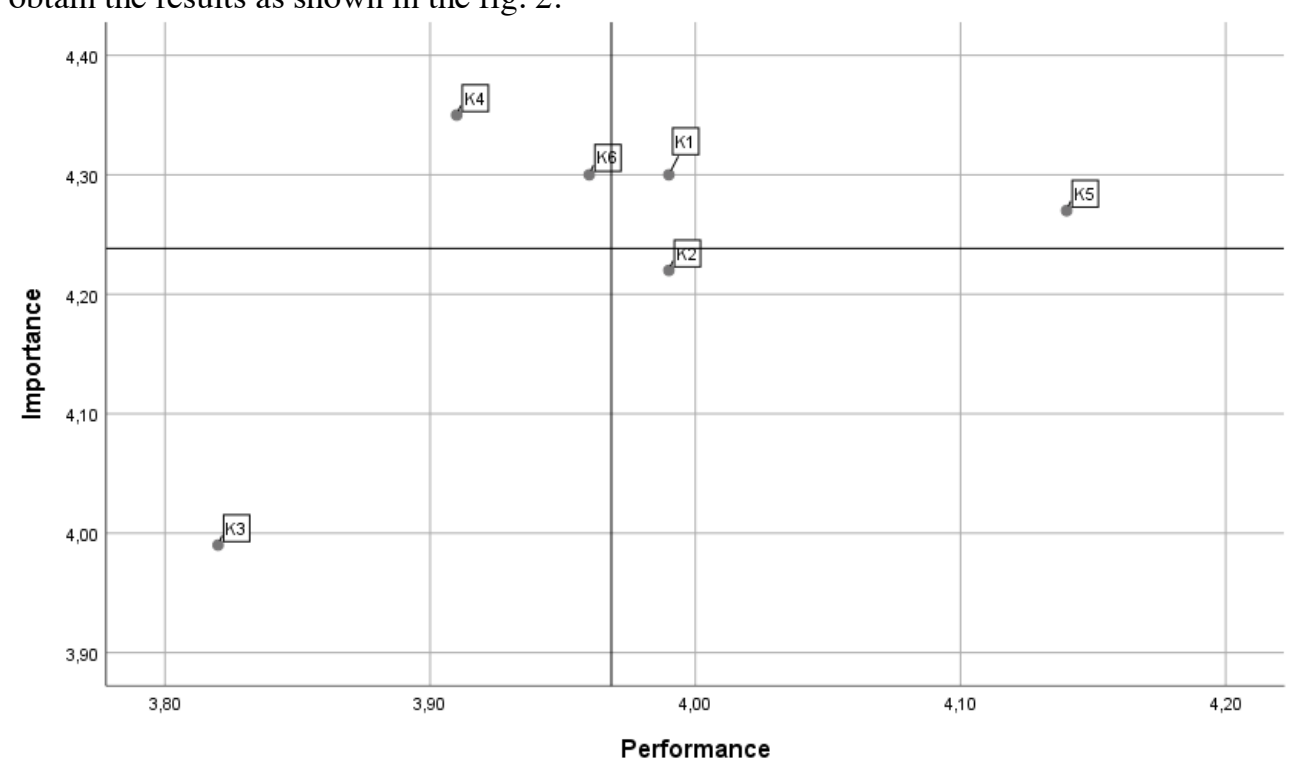

Fig 2. Quadrant graph of IPA

Based on the results of the four quadrant IPA graph in Fig. 2 it can be concluded that the criteria that enter each quadrant based on the PIECES framework can be shown in the table 8 . 
Table 8. IPA Analysis Results

\begin{tabular}{lclc}
\hline \multicolumn{1}{c}{ Variale } & Code & Quadrant & Information \\
\hline Performance & K1 & Quadrant II & Keep up the good work \\
Information and Data & K2 & Quadrant II & Keep up the good work \\
Economics & K3 & Quadrant IV & Possible Overkill \\
Control and Security & K4 & Quadrant III & Low Priority \\
Efficiency & K5 & Quadrant II & Keep up the good work \\
Service & K6 & Quadrant I & Concentrate Here \\
\hline
\end{tabular}

\subsection{Satisfaction Conformity Analysis and User Interests}

The results of the suitability level analysis to determine the level of satisfaction and importance by applying the Importance Performance Analysis method can be shown in table 9.

Table 9. Analyze The Suitability Level

\begin{tabular}{ccc}
\hline $\begin{array}{c}\text { Code } \\
\text { Domain }\end{array}$ & $\begin{array}{c}\text { Calculations } \\
\text { Result }\end{array}$ & Information \\
\hline K1 & $93 \%$ & Keep up the good work \\
K2 & $95 \%$ & Keep up the good work \\
K3 & $96 \%$ & Possible Overkill \\
K4 & $90 \%$ & Low Priority \\
K5 & $97 \%$ & Keep up the good work \\
K6 & $92 \%$ & Concentrate Here \\
\hline
\end{tabular}

\subsection{Discussion Quadran}

Discussion of the results of the IPA quadrant shown in the table. 8 states that the variables of each quadrant, as follows:

1. Quadrant I: Quadrant I show the level of importance is quite high but the satisfaction is relatively low so it needs improvement in terms of increasing user satisfaction of information systems. The variable in this quadrant is $\mathrm{K} 4$ (Control and Security) and K6 (Service).

2. Quadrant II: Quadrant II shows a relatively high level of importance and satisfaction that matches the user's expectations and needs to be maintained. The variables in this quadrant are K1 (Performance) and K5 (Efficiency).

3. Quadrant III: Quadrant III shows the level of importance and satisfaction is low enough so that it does not need improvement because it is not the user's top priority. The variable in this quadrant is $\mathrm{K} 3$ (Economics).

4. Quadrant IV: Quadrant IV shows the level of importance is quite low but has a high level of satisfaction that needs improvement to improve the interests of users. The variable in this quadrant is K2 (Information and Data),

\section{Conclusions}

Based on the results of data calculations on 88 respondents using RKAT Information Systems to evaluate the level of satisfaction and importance of the RKAT information system, the authors can conclude that the system has provided user satisfaction and is considered important in facilitating the budget planning process at Diponegoro University. The results of the suitability level are Performance $92.81 \%$, Information and Data $94.71 \%$, Economics 
95.59\%, Control and Security $89.90 \%$, Effeciency $97.07 \%$, Service $92.20 \%$. for an average yield level of satisfaction and importance of $93.71 \%$. But there is still a need for improvement and further development to increase user satisfaction and interests in the RKAT information system such as system quality, accurate information, estimated costs to build systems, security systems, efficiency and service improvement for users.

\section{Acknowledge}

The preparation and research of this paper were successful with the support and assistance of various parties. The author would like to thank the scholarship program PasTi, from the Ministry of research, technology, and higher education, Indonesia, which provided research funding assistance. Kusworo Adi and Aris Puji Widodo, lecturers in the Information Systems Masters, graduate school, Diponegoro University, who have given directions and guidance on research transcripts and all who have supported and assisted my research.

\section{References}

1. Mardiasmo, Akuntansi Sektor Publik, Yogyakarta: ANDI (2009).

2. Tullah, Rahmat and Muhammad Iqbal Hanafri, Evaluation of information System implementation in Polytechnic LP3I Jakarta with Pieces method. ISSN: 2088-1762. Jakarta: Cursor Scientific Journal, 22-28 (2014).

3. L. Whitten, Jeffrey, \& D. Bentley, Lonnie, System Analysis \& Design Methods Seventh Edition. New York, USA : McGraw-Hill (2007).

4. Supriyatna, Adi, Maria, dan Vivi, Analysis of user satisfaction rate and importance level of application of DJP Online Information System with PIECES framework. ISSN: 2477-698X. Khazanah Informatika, 3 (2017).

5. Lee, H., Measurement of visitor' statisfaction with public zoos in korea using importance-performance analysis, Tourism Management 47, 251-260 (2015).

6. Cohen, J.F., Coleman, E., dan Kangethe, M.J., An Importance-performance analysis of hospital information system attributes. A nurses' perspective, International Journal of Medical Informatics 86, 82-90, 2016.

7. M. Chen, H. Murphy, S. Knecht, An Importance Performance Analysis of smartphone applications for hotel chains, Journal of Hospitality and Tourism Management, 69-79 (2016).

8. Phadermrod, B., Crowder, R.M., and Wills, G.B., Importance-performance Analysis based SWOT Analysis, International Journal of Information Management 44, 194-203 (2019).

9. O'Brien and Marakas, Management Information System. McGraw Hill, New York (2010).

10. Laudon, Kenneth C \& Laudon, Jane P., Manegement Information System: Managing Digital Companies Issue 13. Jakarta: Salemba four publisher (2014).

11. Rellanti Diana Kristy dan Wahyu Andhyka Kusuma, Level of satisfaction analysis and importance of implementation of information system Muhammadiyah University Malang. ISSN:2579-5422. Malang: Teknika: Engineering and Sains Journal, 2, Juni 2018, 17-24 (2018).

12. Wu, C.H., Lee, Y.C., Cheng, Y.C., dan Tasi, S.B., The use of Importance Performance Analysis (IPA) in evaluating bank services, International Conference on Service Systems and Service Management (ICSSSM), 654-657 (2012).

13. C. M. N. Faisal, M. Gonzalez-Rodriguez, D. FernandezLanvin, and J. De Andres- 
Suarez, Web Design Attributes in Building User Trust, Satisfaction, and Loyalty for a High Uncertainty Avoidance Culture. IEEE Trans. Human-Machine Syst., 47, no. 6, pp. 847859 (2017).

14. Padlee S.F., Reimers V., Mokhlis S., Anuar M.M., Ahmad A., Keep Up The Good Work In Research Universities: An Importance-Performance Analysis. Australasian Marketing Journal, 8-9 (2019).

15. Sugiyono, Quantitative, Qualitative, and R\&D Research Methods. Bandung: Alfabeta, CV. (2017).

16. Sugiyono, Research Methods in Business, Alfabeta, Bandung (2017).

17. Sugiyono, Quantitative, Qualitative, and R\&D Research Methods. Bandung: Alfabeta (2018).

18. Ong, J.O., and Pambudi, J., Analysis of Customer Satisfaction with Importance Performance Analysis at SBU Laboratory Cibitung PT. Sucofindo (Persero). J@TI Undip Journal, 9, 1-10 (2014).

19. Rizal Nugraha, Amba Harsono, Amba, Adianto, Hari. Proposed Improvement of Service Quality at Workshop "X" Based on the Results of the ImportancePerformance Analysis Matrix (Case study at AHASS Workshop PD. Sumber Motor Karawang). Online Journal of the National Institute of Technology, 221231 (2014).

20. J.A. Martila, J. James, Journal of Marketing 41, 77 (1977). 